\title{
Influence of body position on the measurement of electrocardiographic waves in healthy $\operatorname{dogs}^{1}$
}

\author{
Marlos G. Sousa $^{2 *}$, Mariana C.H. Rondelli² ${ }^{2}$ Sheila S.S. Nogueira ${ }^{2}$ and Roberta Carareto ${ }^{2}$ \\ ABSTRACT.- Sousa M.G., Rondelli M.C.H., Nogueira S.S. \& Carareto R. 2018. Influence of body \\ position on the measurement of electrocardiographic waves in healthy dogs. Pesquisa \\ Veterinária Brasileira 38(2):340-344. Departamento de Medicina Veterinária, Universidade \\ Federal do Paraná, Rua dos Funcionários 1540, Cabral, Curitiba, PR 80035-050, Brazil. \\ E-mail: marlos98@ufpr.br \\ The agreement between the electrocardiographic waves measured from tracings \\ recorded in right lateral recumbency and several other unusual body positions was assessed. \\ Electrocardiograms were recorded in 160 healthy dogs in right lateral, left lateral, dorsal and \\ sternal recumbencies, as well as in standing position. Considering the right lateral recordings \\ as the gold standard, the lowest biases for the majority of ECG parameters were calculated \\ from left lateral recordings, whereas the highest biases were documented from dorsal \\ and standing positions. For the mean electrical axis, the dorsal recumbency produced the \\ lowest bias, while the greatest one was identified in sternal position. An analysis of variance \\ indicated differences when the means of P wave duration and amplitude, duration of QRS \\ and QT, and mean electrical axis obtained in unusual positions were compared with right \\ lateral. In conclusion, left lateral recumbency produced the most similar measurements as \\ compared to right lateral, but the wide limits of agreement preclude the use and interpretation \\ of these positions interchangeably. \\ INDEX TERMS: Body position, electrocardiographic waves, electrocardiography, dogs, body positioning, \\ veterinary cardiology, ECG waves, ECG measurement.
}

\begin{abstract}
RESUMO.- [Influência do posicionamento corporal na mensuração das ondas eletrocardiográficas em cães sadios.] A concordância entre a mensuração das ondas eletrocardiográficas a partir de traçados registrados em cães mantidos em decúbito lateral direito e em vários outros posicionamentos corporais foi avaliada nesta pesquisa. Para tanto, traçados eletrocardiográficos de 160 cães saudáveis foram registrados com os pacientes posicionados nos decúbitos lateral direito, lateral esquerdo, dorsal e esternal, assim como em posição quadrupedal. Tomando como padrão ouro os registros obtidos em decúbito lateral direito, as menores diferenças médias para a maioria dos parâmetros eletrocardiográficos foram obtidas a partir dos traçados registrados com o cão mantido em decúbito lateral esquerdo, enquanto as maiores diferenças médias foram documentadas nos registros obtidos nos decúbitos dorsal e quadrupedal. Para o eixo elétrico
\end{abstract}

\footnotetext{
${ }^{1}$ Received on October 13, 2016. Accepted for publication on April 6, 2017.

${ }^{2}$ Departamento de Medicina Veterinária, Universidade Federal do Paraná (UFPR), Rua dos Funcionários 1540, Cabral, Curitiba, PR 80035-050, Brasil. *Corresponding author: marlos98@ufpr.br
}

médio, o decúbito dorsal produziu a menor diferença média, enquanto a maior foi identificada no registro em posição esternal. A análise de variância mostrou diferenças entre as médias da duração e amplitude da onda P, duração do QRS e do intervalo QT e o eixo elétrico médico quando as posições não usuais foram comparadas com o decúbito lateral direito. Esta pesquisa mostrou que o decúbito lateral esquerdo produziu as medidas mais semelhantes quando comparado àquelas obtidas em decúbito lateral direito. No entanto, os limites de concordância amplos impedem que essas posições sejam utilizadas e interpretadas de maneira intercambiável.

TERMOS DE INDEXAÇÃO: Posicionamento corporal, ondas eletrocardiográficas, caninos, eletrocardiografia, cardiologia veterinária, mensuração eletrocardiográfica.

\section{INTRODUCTION}

Although the last two decades has seen the introduction of several novel diagnostic methods in the daily practice of small animal cardiology, the electrocardiogram (ECG) remains a fundamental part in the assessment of cardiac problems, 
being, continued through today, the gold standard for the diagnosis of heart rhythm disturbances. Therefore, it not surprising that electrocardiography is used in different clinical scenarios, including pre-anesthetic evaluation, identification and classification of arrhythmias, and, less specifically, to detect chamber enlargement in patients with heart disease (Strickland 2007).

Nonetheless, to be confidently interpreted, the ECG needs to be recorded under a series of guidelines, which include the position of the body during signal acquisition. It is required that the animal be positioned on a nonconductive surface to eliminate electrical interference, having its limbs perpendicular to the long axis of the body and parallel to each other (Tilley \& Smith 2015). The electrode clips are attached directly to the animal's skin and should be moistened with conductive gel or alcohol (Tilley 1992).

The right lateral recumbency is the standard position of body during recording, to which all normal ranges for the electrocardiographic waves have been determined and are available (Kittleson 1998). Unfortunately, there are several conditions that preclude a proper restraint of the animal during the ECG recording, which may compromise the acquisition process and, therefore, its interpretation. In patients difficult to restrain, the use of drugs is usually not recommended because it might interfere with the cardiac cycle. Also, patients in respiratory distress may be hard to be properly positioned on the table (Tilley 1992, Tilley \& Smith 2015). In these cases, the ECG will likely be recorded in an unusual position, although it is not completely known how the electrocardiographic waves perform in different body positions other than the standard one.

Although some studies have been done previously, the majority of them included only a few subjects. In this investigation, the authors hypothesized that in a large canine population the electrocardiographic waves would not differ between the standard right lateral recumbency and other unusual body positions. Therefore, the purpose of this study was twofold: to assess how the measurements of eletrocardiographic waves obtained from ECG tracings recorded with the animal restrained in an unusual body position compare with the same measurements obtained from the standard right lateral recumbecy, and to investigate whether these body positions may be used interchangeably during ECG recording and interpretation.

\section{MATERIALS AND METHODS}

Animals. This investigation was conceived as a crossover study using a convenience sample. One hundred-sixty client-owned mature dogs $(13.2 \pm 11.8 \mathrm{~kg})$ aged $13-52$ months of either sex were used. Several breeds were represented, including Dachshunds (12/160), Lhasa-Apso (11/160), Miniature Pinscher (10/160), Shih Tzu (9/160), Brazilian Terrier (9/160), English Cocker Spaniel (8/160), Australian Cattle Dog (7/160), Yorkshire Terrier (5/160), Pug (4/160), Beagle (3/160), Schnauzer (3/160), and Maltese (2/160). Poodles (29/160) and mixed-breed dogs (48/160) were overrepresented. All animals enrolled in the study were brought to a Veterinary Teaching Hospital for various purposes, including routine vaccinations and neutering. After owner written consent was granted, all animals were determined to be healthy based on results of physical examinations and ancillary laboratory tests, including complete blood count and routine serum biochemistry. The identification of soft grade
1-3 murmurs on auscultation did not preclude the inclusion of the dog into the study population, as long as they did not present any rhythm other than sinus rhythm or respiratory sinus arrhythmia on auscultation and exhibited no signs which could be ascribed to cardiac diseases. The investigation was entirely conducted in accordance with guidelines outlined in the National Institutes of Health Guide for the Care and Use of Laboratory Animals and was approved by the institutional committee on the ethics in animal experimentation.

Electrocardiograms. Computer-based electrocardiograms were recorded in all dogs with a speed of $50 \mathrm{~mm} / \mathrm{s}$, and calibration set at $10 \mathrm{~mm} / \mathrm{mV}$. The animals were randomly (http://www.random.org) restrained in five different body positions, including the standard right lateral recumbency (RL), as well as the unusual left lateral (LL), dorsal (DO), sternal (STE) recumbencies, and in standing position (STA). For each one, an ECG was recorded for approximately three minutes. Using lead II tracings, a single, experienced veterinary cardiologist was responsible for the measurements of the duration of $\mathrm{P}$ wave $\left(\mathrm{P}_{\mathrm{ms}}\right)$, $\mathrm{P}$ wave amplitude $\left(\mathrm{P}_{\mathrm{mV}}\right)$, duration of PR interval (PR), duration of QRS complex (QRS), $R$ wave amplitude (R), duration of QT interval (QT), mean electrical axis (MEA), and heart rate (HR) in all ECG recordings as reported elsewhere (Tilley 1992, Tilley \& Smith 2015).

Statistical analyses. The agreement between the standard right lateral recumbency and every unusual position was assessed using Bland-Altman, in which the difference between two techniques (RL versus LL, DO, STE, and STA) is plotted against their mean and the limits of agreement calculated (Bland and Altman 1986). Biases were calculated and the results expressed as the mean, standard deviation and 95\% limits of agreement. Also, a repeated-measures analysis of variance was performed to look for differences between body positions for each of the studied parameters. When differences were determined to exist, the Tukey-Kramer post-hoc test was used to further investigate differences among the several recording positions. For all analyses, significance was set at $\mathrm{P}<0.05$.

\section{RESULTS}

Table 1 gives the results of Bland-Altman analysis, including the biases, standard deviations, and the $95 \%$ limits of agreement for every parameter measured in all unusual position as compared to the standard right lateral recumbency. In comparison with $\mathrm{RL}$, the recordings in LL disclosed the lowest biases for the majority of ECG measurements, including the duration of $\mathrm{P}$ wave (mean bias \pm standard deviation: $0.3125 \pm 11.7400$ ), amplitude of $P$ wave $(0.0031 \pm 0.0738)$, PR interval $(0.875 \pm 12.520)$, amplitude of $\mathrm{R}$ wave $(-0.0043 \pm 0.2286)$, and QT interval $(12.25 \pm 44.31)$. For the duration of QRS complex, the lowest bias was documented in the STE recording (-2.938 \pm 10.870$)$. On the contrary, the highest biases for the duration of $\mathrm{P}$ wave (5.00 \pm 14.14$), Q R S$ complex ( $-5.063 \pm 12.250)$, and amplitude of R wave $(-0.0762 \pm 0.3719)$ were documented in D0 recumbency, whereas the STA position presented the highest ones for the amplitude of P wave ( $0.0356 \pm 0.1011)$, PR interval (5.00 \pm 21.57$)$ and QT interval (18.31 \pm 38.95$)$. The lowest bias for MEA was documented in DO (1.5118 \pm 35.2850$)$, while the greatest one was found in STE (32.1088 \pm 60.6746$)$ tracings.

Regarding the analysis of variance, statistical differences $(\mathrm{P}>0.05)$ were identified between positions when the means of the duration and amplitude of $P$ wave, the duration of QRS complex, QT interval, and MEA obtained in the unusual positions were compared with RL (Table 2). On the other hand, 
Table 1. Bias (average difference) and limits of agreement between ECG measurements obtained in right lateral recumbency and other non-standard body positions in 160 healthy mature non-sedated dogs

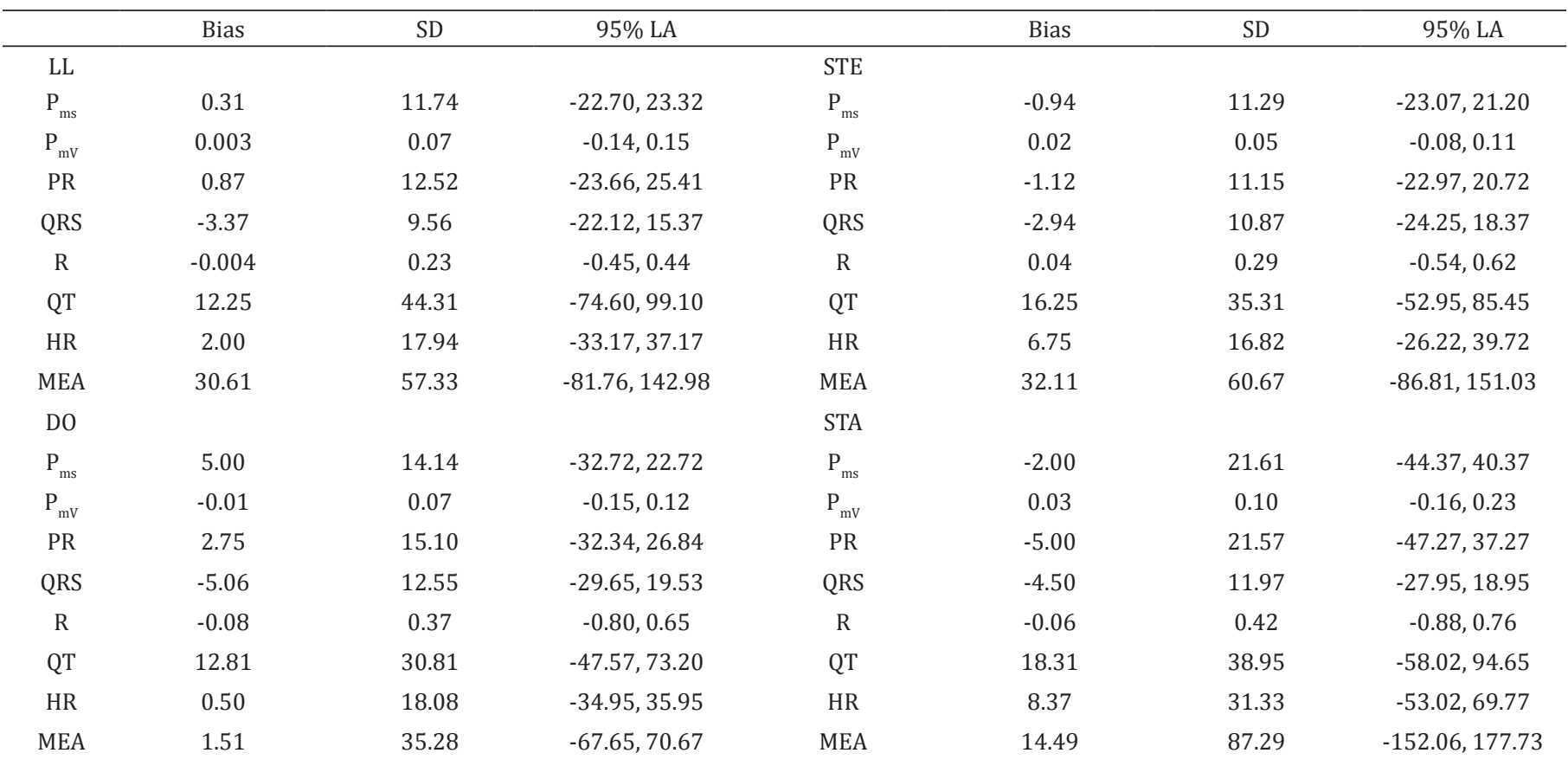

$\overline{\mathrm{SD}}=$ standard deviation, $\mathrm{LA}=$ limits of agreement, $\mathrm{LL}=$ left lateral recumbency, DO = dorsal recumbency, STE = sternal position, $\mathrm{STA}=$ standing position, $\mathrm{Pms}=$ duration of $\mathrm{P}$ wave, $\mathrm{PmV}=\mathrm{P}$ wave amplitude $\mathrm{PR}=$ duration of $\mathrm{PR}$ interval, $\mathrm{QRS}=$ duration of $\mathrm{QRS}$ complex, $\mathrm{R}=\mathrm{R}$ wave amplitude, $\mathrm{QT}=\mathrm{duration}$ of $\mathrm{QT}$ interval, MEA = mean electrical axis, $\mathrm{HR}=$ heart rate.

Table 2. Mean, standard deviation and $95 \%$ confidence intervals of ECG parameters measured from tracings recorded in healthy mature non-sedated dogs $(n=160)$ restrained in the standard right lateral recumbency and several other unusual body positions

\begin{tabular}{|c|c|c|c|c|c|c|}
\hline & RL & LL & DO & STE & STA & $P$ \\
\hline $\mathrm{P}_{\mathrm{ms}}$ & $\begin{array}{l}54.7 \pm 10.7^{\mathrm{A}} \\
(53.0-56.4)\end{array}$ & $\begin{array}{c}55.0 \pm 8.2^{\mathrm{A}} \\
(53.7-56.3)\end{array}$ & $\begin{array}{c}49.7 \pm 9.6^{\mathrm{B}} \\
(48.2-51.2)\end{array}$ & $\begin{array}{c}53.8 \pm 9.7^{\mathrm{A}} \\
(52.3-55.3)\end{array}$ & $\begin{array}{l}52.7 \pm 16.9^{\mathrm{AB}} \\
(50.1-55.3)\end{array}$ & $<0.0001$ \\
\hline $\mathrm{P}_{\mathrm{mV}}$ & $\begin{array}{l}0.16 \pm 0.08^{\mathrm{A}} \\
(0.15-0.17)\end{array}$ & $\begin{array}{c}0.16 \pm 0.07^{\mathrm{AB}} \\
(0.15-0.17)\end{array}$ & $\begin{array}{c}0.15 \pm 0.07^{\mathrm{A}} \\
(0.14-0.16)\end{array}$ & $\begin{array}{c}0.18 \pm 0.06^{\mathrm{BC}} \\
(0.17-0.19)\end{array}$ & $\begin{array}{c}0.20 \pm 0.08^{\mathrm{C}} \\
(0.19-0.21)\end{array}$ & 0.0016 \\
\hline PR & $\begin{array}{c}103.8 \pm 18.7 \\
(100.9-106.7)\end{array}$ & $\begin{array}{c}104.6 \pm 18.8 \\
(101,7-107,5)\end{array}$ & $\begin{array}{c}101.0 \pm 19.0 \\
(98.1-103.9)\end{array}$ & $\begin{array}{c}102.6 \pm 21.5 \\
(99.3-105.9)\end{array}$ & $\begin{array}{c}98.8 \pm 28.5 \\
(94.4-103.2)\end{array}$ & 0.1199 \\
\hline QRS & $\begin{array}{c}56.9 \pm 8.5^{A} \\
(55.6-58.2)\end{array}$ & $\begin{array}{c}53.5 \pm 6.4^{\mathrm{B}} \\
(52.5-54.5)\end{array}$ & $\begin{array}{l}51.8 \pm 10.2^{\mathrm{B}} \\
(50.2-53.4)\end{array}$ & $\begin{array}{c}53.9 \pm 8.3^{\mathrm{B}} \\
(52.6-55.2)\end{array}$ & $\begin{array}{l}52.4 \pm 11.2^{\text {B }} \\
(50.7-54.1)\end{array}$ & $<0.0001$ \\
\hline $\mathrm{R}$ & $\begin{array}{c}0.90 \pm 0.44 \\
(0.83-0.97)\end{array}$ & $\begin{array}{c}0.92 \pm 0.47 \\
(0.85-0.99)\end{array}$ & $\begin{array}{c}0.85 \pm 0.47 \\
(0.78-0.92)\end{array}$ & $\begin{array}{c}0.96 \pm 0.44 \\
(0.89-1.03)\end{array}$ & $\begin{array}{c}0.86 \pm 0.51 \\
(0.78-0.94)\end{array}$ & 0.2052 \\
\hline QT & $\begin{array}{c}182.4 \pm 32.4^{\mathrm{A}} \\
(177.4-187.4)\end{array}$ & $\begin{array}{c}195.7 \pm 45.4^{\mathrm{B}} \\
(188.7-202.7)\end{array}$ & $\begin{array}{c}196.3 \pm 23.7^{\text {B }} \\
(192.6-200.0)\end{array}$ & $\begin{array}{c}199.7 \pm 24.0^{\text {В }} \\
(196.0-203.4)\end{array}$ & $\begin{array}{c}201.8 \pm 34.7^{\text {B }} \\
(196.4-207.2)\end{array}$ & $<0.0001$ \\
\hline HR & $\begin{array}{c}124.9 \pm 26.7 \\
(120.8-129.0)\end{array}$ & $\begin{array}{c}126.9 \pm 30.7 \\
(122.1-131.7)\end{array}$ & $\begin{array}{c}125.4 \pm 32.7 \\
(120.3-130.5)\end{array}$ & $\begin{array}{c}131.7 \pm 33.7 \\
(126.5-136.9)\end{array}$ & $\begin{array}{c}133.3 \pm 43.4 \\
(126.6-140.0)\end{array}$ & 0.0879 \\
\hline MEA & $\begin{array}{l}55.1 \pm 24.6^{\mathrm{AC}} \\
(51.3-58.9)\end{array}$ & $\begin{array}{l}66.3 \pm 26.8^{\text {B }} \\
(62.1-70.5)\end{array}$ & $\begin{array}{l}48.3 \pm 23.2^{\mathrm{A}} \\
(44.7-51.9)\end{array}$ & $\begin{array}{l}68.3 \pm 18.6^{\text {B }} \\
(65.4-71.2)\end{array}$ & $\begin{array}{c}57.8 \pm 37.7^{c} \\
(52.0-63.3)\end{array}$ & $<0.0001$ \\
\hline
\end{tabular}

RL: right lateral recumbency; LL: left lateral recumbency; DO: dorsal recumbency; STE: sternal position; STA: standing position, QT: duration of QT interval.

the means of PR interval, $\mathrm{R}$ wave amplitude, and heart rate were considered similar regardless of the position in which the ECG was recorded. Also, when the measurements of a given parameter obtained in an unusual position was compared with the same measurement obtained in the standard RL, the
LL recumbency produced most of the lowest median percent changes (for the duration of $\mathrm{P}$ wave, $\mathrm{PR}$ interval, $\mathrm{R}$ wave amplitude, and QT interval), followed by DO (amplitude of $\mathrm{P}$ wave and HR) and STE (duration of QRS complex and MEA) recumbencies (Fig.1). 


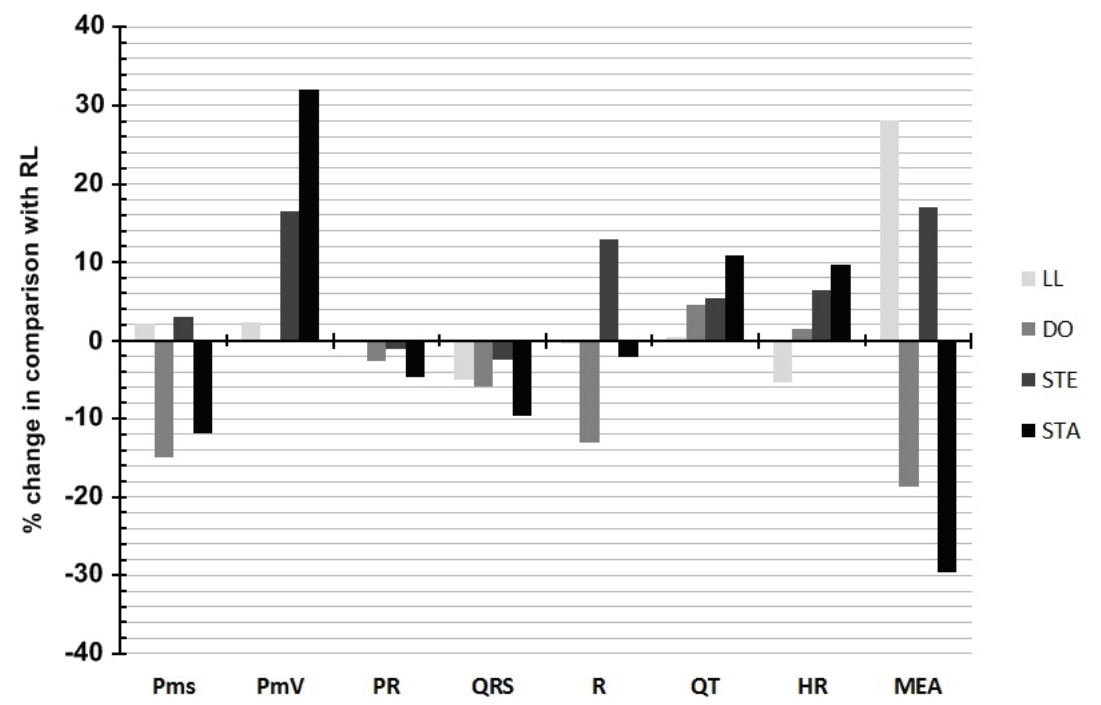

Fig.1. Representation of the median percent change for each ECG parameter considering the measurements documented in a given unusual position and the same measurement obtained in the standard right lateral recumbency of dogs.

\section{DISCUSSION}

Bland-Altman plots revealed a better overall agreement between right and left lateral recumbencies. The comparison of these two positions produced five of the lowest calculated biases. As an example, the bias, or average difference between the two positions, was $0.0031 \mathrm{mV}$ for the amplitude of $\mathrm{P}$ wave in this situation, with limits of agreement showing that the discrepancy between the usual and unusual position (right versus left recumbencies) for an individual animal ranged from -0.1416 to $0.1478 \mathrm{mV}$. If we arbitrarily consider any error greater than $0.1 \mathrm{mV}$ to be clinically unacceptable for this parameter, it becomes obvious that there is a lack of agreement between the two positions regarding the measurement of $\mathrm{P}$ wave amplitude. This same interpretation is valid for the several parameters that were studied in this investigation. While the bias may be acceptable for some of them, the limits of agreement of every parameter attained lack of agreement between right lateral recumbency, which is considered the standard position, and the remainder of body positioning. The two positions that produced more parameters with the greatest bias were DO and STA, with three variables for each of them. Therefore, one might speculate that these positions are unacceptable for clinical purposes when compared with RL.

Although the analysis of variance did not document differences between the standard RL and the unusual positions for PR, R, and HR in this study, caution should be exercised when analyzing this result because it is not considered to be an appropriate analysis when comparing methods to determine the same parameter. Nonetheless, the amplitude of $\mathrm{P}$ wave, the duration of PR interval, the amplitude of $\mathrm{R}$ wave, and the duration of QT interval are within the normal ranges proposed for dogs restrained in the standard right lateral recumbency (Tilley 1992). On the contrary, the duration of $P$ wave and QRS complex recorded in the unusual positions were higher than those proposed elsewhere (Wolf et al. 2000, Tilley \& Smith 2015). This condition may be ascribed not only to the unusual positioning of the animals, but also to differences attributable to the ECG equipment. When using a computer-based analysis in healthy dogs, a previous study identified significantly higher amplitude and duration of $\mathrm{P}$ wave, as well as a more prolonged duration of QRS complex in comparison with the paper-based electrocardiogram (Wolf et al. 2000).

In a similar study that evaluated the six-lead electrocardiograms of 39 healthy dogs restrained in right and left lateral recumbencies, and in standing position (Rishniw et al. 2002), the analysis of lead II showed an increased $\mathrm{R}$ wave amplitude in both standing position and left lateral recumbency, contrasting with our data, in which $\mathrm{R}$ wave amplitude was within the normal range reported for paper-based ECG (Tilley 1992) and using the same computer-based analysis (Wolf et al. 2000). In another investigation that assessed the six-lead electrocardiograms of 31 dogs without heart disease restrained in right lateral recumbency, and in seating and sternal positions (Coleman and Robson 2005), the results showed augmented amplitudes of $\mathrm{P}$ and $\mathrm{R}$ waves in lead II when the ECG was recorded with the dogs positioned in sternal recumbency, contrasting with this study, whose data did not document changes when the dogs were restrained in the same position.

In a more recent study, Stern et al. (2013) evaluated 65 sled dogs in both RL and STA positions using lead II and three semi-orthogonal leads. Different from our results, they identified a shorter QRS duration using RL as compared to that documented with the dogs standing, which was ascribed to RL presenting less muscle tremor artifact. Nevertheless, the analysis of STA recording found a $20^{\circ}$ rightward shift in MEA relative to $\mathrm{RL}$, which is quite similar to the bias of $14.49^{\circ}$ found when these two positions were compared in this study.

In cats, $R$ wave amplitude was reduced in both STE and LL when compared with RL recumbency. However, the MEA only was significantly different in LL. The authors concluded that STE and LL recumbencies should not be used for recording electrocardiograms if amplitudes and MEA are to be compared with the standard references for RL (Harvey et al. 2005). 
One of the biggest limitations of this study relies on the convenience sample that was enrolled. Animals presented only rhythms considered to be normal, and no pathological arrhythmia was included at all. Also, even greater biases might be expected if the measurements are to be performed by a veterinarian that is not familiar with ECG interpretation.

Our results are particularly important to address whether ECG measurements should be considered when the standard acquisition position is not possible owing to the animal's clinical conditions. Animals in respiratory distress, cardiac tamponade, or trauma, for instance, are prone to have an ECG recorded under an unusual position. In such situation, the veterinary practitioner must be aware that the interpretation of ECG wave measurements should not rely on the normal ranges available for the right lateral recumbency.

\section{CONCLUSIONS}

According to the calculated biases, LL recumbency was demonstrated to be the unusual position of ECG recording that presented the most similar measurements as compared to the standard RL position in dogs.

The wide limits of agreement preclude the use of these positions interchangeably.

Further studies are truly warranted to assess such unusual positions for ECG recording in dogs with rhythm disturbances and cardiac diseases.

Acknowledgments.- The authors thank Conselho Nacional de Desenvolvimento Científico e Tecnológico (CNPq) for the financial support of this study.

\section{REFERENCES}

Bland J.M. \& Altman D.G. 1986. Statistical methods for assessing agreement between two methods of clinical measurement. Lancet 1(8476):307-310. PMid:2868172. http://dx.doi.org/10.1016/S0140-6736(86)90837-8.

Coleman M.G. \& Robson M.C. 2005. Evaluation of six-lead electrocardiograms obtained from dogs in a sitting position or sternal recumbency. Am. J. Vet. Res. 66(2):233-237. PMid:15757120. http://dx.doi.org/10.2460/ajvr.2005.66.233.

Harvey A.M., Faena M., Darke P.G.G. \& Ferasin L. 2005. Effect of body position on feline electrocardiographic recordings. J. Vet. Intern. Med. 19(4):533-536. PMid:16097093. http://dx.doi.org/10.1111/j.1939-1676.2005.tb02723.x.

Kittleson M.D. 1998. Electrocardiography: basic concepts, diagnosis of chamber enlargement, and intraventricular conduction disturbances, p.72-94. In: Kittleson M.D. \& Kienle R.D. (Eds), Small Animal Cardiovascular Medicine. Mosby, St Louis.

Rishniw M., Porciello F., Erb H.N. \& Fruganti G. 2002. Effect of body position on the 6-lead ECG of dogs. J. Vet. Intern. Med. 16(1):69-73. PMid:11822807. http://dx.doi.org/10.1111/j.1939-1676.2002.tb01608.x.

Stern J.A., Hinchcliff K.W. \& Constable P.D. 2013. Effect of body position on electrocardiographic recordings in dogs. Aust. Vet. J. 91(7):281-286. PMid:23782021. http://dx.doi.org/10.1111/avj.12076.

Strickland K. 2007. Feline and canine electrocardiographic evaluation. Disponível em <http://www.ivis.org/proceedings/navc/2007/SAE/066.asp?LA=1> Acessado em Feb. 10, 2016.

Tilley L.P.1992. Essentials of Canine and Feline Electrocardiography: interpretation and treatment. 3rd ed. Lea and Febiger, Philadelphia.

Tilley L.P. \& Smith F.W.K. Jr 2015. Electrocardiography, p.49-76. In: Smith Jr F.W.K., Tilley L.P., Oyama M.A. \& Sleeper M.E. (Eds), Manual of Canine and Feline Cardiology. 5th ed. Elsevier, St Louis.

Wolf R., Camacho A.A. \& Souza R.C.A. 2000. Computerized electrocardiography in dogs. Arq. Bras. Med. Vet. Zootec. 52:610-615. http://dx.doi.org/10.1590/ S0102-09352000000600010. 